\title{
Hepatocellular carcinoma patients are advantaged in the current Brazilian liver transplant allocation system. A competing risk analysis
}

\author{
Santiago RODRíGUEZ ${ }^{1}$, Alfeu de Medeiros FLECK JR ${ }^{2}$, Marcos MUCENIC ${ }^{2}$, \\ Cláudio MARRONI ${ }^{1,2}$ and Ajacio BRANDÃO ${ }^{1,2}$
}

Received: 23 August 2019 Accepted: 27 October 2019

\begin{abstract}
Background - In Brazil, the Model for End-Stage Liver Disease (MELD) score is used to prioritize patients for deceased donor liver transplantation (DDLT). Patients with hepatocellular carcinoma (HCC) receive standardized MELD exception points to account for their cancer risk of mortality, which is not reflected by their MELD score. Objective - To compare DDLT rates between patients with and without HCC in Rio Grande do Sul, the Southernmost state of Brazil. Methods - We retrospectively studied 825 patients on the liver-transplant waiting list from January 1, 2007, to December 31, 2016, in a transplant center located in Porto Alegre, the capital of Rio Grande do Sul, to compare DDLT rates between those with and without HCC. The time-varying hazard of waiting list/DDLT was estimated, reporting the subhazard ratio (SHR) of waiting list/DDLT/dropout with 95\% confidence intervals (CI). The final competing risk model was adjusted for age, MELD score, exception points, and ABO group. Results - Patients with HCC underwent a transplant almost three times faster than patients with a calculated MELD score (SHR 2.64; 95\% CI 2.10-3.31; $P<0.001)$. The DDLT rate per 100 person-months was 11.86 for HCC patients vs 3.38 for non-HCC patients. The median time on the waiting list was 5.6 months for patients with HCC and 25 months for patients without HCC. Conclusion - Our results demonstrated that, in our center, patients on the waiting list with HCC have a clear advantage over candidates listed with a calculated MELD score.
\end{abstract}

HEADINGS - Liver transplantation. Hepatocellular carcinoma. Organ transplantation. Healthcare disparities.

\section{INTRODUCTION}

With the primary objective of reducing mortality among patients on the waiting list for deceased donor liver transplantation (DDLT), in July 2006, the Brazilian National Transplant System (Sistema Nacional de Transplantes, SNT), coordinated by the Brazilian Ministry of Health ${ }^{(1)}$, changed the criteria for allocation of deceased donor allografts, which were based exclusively on time on the waiting list, to severity-based criteria. The SNT adopted the Model for End-Stage Liver Disease (MELD) scoring system to rank patients according to their clinical urgency. The MELD score, which is calculated using serum bilirubin, international normalized ratio (INR) of prothrombin time, and serum creatinine, provides an objective score to accurately determine the risk of short-term mortality for patients with chronic liver disease $\mathrm{e}^{(2,3)}$.

However, the MELD score may not reflect prognosis in all cases, as it is based on liver function, and some conditions require prioritization because they do not share similar mortality rates and may have disease progression as a driving factor. In patients with hepatocellular carcinoma (HCC), the cancer rather than parenchymal disease, reflected by the MELD score, may determine the prognosis. In the MELD-based allocation system, wait-listed HCC patients, many of whom with preserved synthetic liver function, would be competing for scarce donor grafts with noncompetitive determinants of priority, i.e., lower MELD scores. Based on studies on tumor growth that estimated a waiting list dropout rate of $15 \%$ for one tumor $<2 \mathrm{~cm}$ and of $30 \%$ for one tumor $2-5 \mathrm{~cm}$ or 2-3 tumors, $\leq 3 \mathrm{~cm}$ each, in the United States, it was determined that the MELD scores for these patients should be 24 and 29, respectively $y^{(4,5)}$. Additional "exception points" were granted every three months if the patient with HCC remained within the Milan criteria $^{(6,7)}$. Therefore, in that country, in parallel to the introduction of the MELD score and priority exception points for patients with $\mathrm{HCC}$, the percentage of DDLT performed for HCC increased from $7 \%$ to $22 \%$, and most patients underwent a transplant within three months of waiting list registration ${ }^{(8)}$. Furthermore, compared with non-HCC patients, candidates with HCC have been consistently shown to have greater access to DDLT and lower dropout rates ${ }^{(9-12)}$.

In the United States, in order to avoid the prioritization of HCC patients over other patients on the DDLT waiting list, adjustments and changes have been made to these "exception points". Thus, since 2015, patients with a new initial HCC exception application must be registered with their calculated MELD (cMELD) score. At six months, candidates will receive a score of 28. Extensions are applied every three months and, if granted, the MELD score is increased to 30,32 , and then $34^{(13)}$.

In Brazil, since the introduction of the MELD score for allocation of deceased donor grafts, standardized MELD exception

Declared conflict of interest of all authors: none

Disclosure of funding: no funding received

${ }^{1}$ Universidade Federal de Ciências da Saúde de Porto Alegre (UFCSPA), Faculdade de Medicina, Programa de Pós-Graduação em Medicina, Hepatologia, Porto Alegre, RS, Brasil. ${ }^{2}$ Santa Casa de Misericórdia de Porto Alegre, Grupo de Transplante de Fígado, Porto Alegre, RS, Brasil.

Corresponding author: Ajacio Brandão. E-mail: ajaciob@gmail.com 
points that are assigned by the SNT to patients with HCC have not been changed, and their impact on allocation has not been evaluated. The objective of this study was to compare DDLT rates between patients with and without HCC in Rio Grande do Sul, the Southernmost state of Brazil.

\section{METHODS}

\section{Study population}

This was a retrospective cohort study. Eligible participants were all patients aged $>18$ years, of both sexes, who were listed for DDLT from January 2007 to December 2016 in a transplant center located in Porto Alegre, the capital of Rio Grande do Sul.

Patients on the waiting list due to severe acute liver failure, need for liver retransplantation, and approved non-HCC exception points were excluded.

The primary exposure was HCC. To this end, candidates approved for HCC exception points (HCC candidates) were identified and their waiting list outcomes were compared to those of candidates without HCC (non-HCC candidates). Patients were followed until December 31, 2017, to potentially have at least 1-year follow-up.

This study followed the guidelines for reporting observational studies $^{(14)}$ and was approved by the institutional research ethics committee. Informed consent was waived due to the non-interventional design of the study and retrospective nature of data collection. All investigators signed a data use agreement to ensure the ethical and secure use of the data.

\section{Priority for patients with HCC}

Patients with HCC are included in the waiting list with exception points when imaging tests based on the Barcelona Consensus Statements ${ }^{(14)}$ and the Guidelines of the American Association for the Study of Liver Diseases ${ }^{(15)}$ identify one lesion $\geq 2 \mathrm{~cm}$ and $\leq 5 \mathrm{~cm}$, or two or three $\geq 2 \mathrm{~cm}$ and $\leq 3 \mathrm{~cm}$, with no indication for resection. In other words, lesions $<2 \mathrm{~cm}$ are not considered a small modification of the Milan criteria. Tumor progression on chest tomography and bone scintigraphy should be excluded. In our center, when the expected waiting time for liver transplantation is greater than six months, patients receive locoregional therapy: percutaneous ethanol injection (PEI), radiofrequency ablation (RFA), or transcatheter arterial chemoembolization (TACE), according to the number, size and location of nodules ${ }^{(16)}$. HCC patients are included in the waiting list with the following extra points granted: 20 points at listing, 24 after three months, and 29 after six months. Patients receive increasing points as long as they continue to meet the Brazilian modified Milan criteria ${ }^{(1)}$. In Rio Grande do Sul, since its implementation, the number of points assigned to patients with $\mathrm{HCC}$ has not been changed.

\section{Waiting list mortality/dropout}

For the purposes of this analysis, a waiting list mortality/ dropout for an HCC registration occurred for any of the following withdrawals: death on the waiting list; patient is too sick to undergo a transplant; or contraindication related to HCC (defined as tumor progression beyond the modified Milan criteria, metastatic disease, and/or presence of macrovascular invasion on imaging examination). A waiting list mortality/dropout for non-HCC registration was defined similarly, except for the withdrawals related to $\mathrm{HCC}$.

\section{Statistical analysis}

Patient characteristics were expressed as mean and standard deviation for continuous variables and as counts and percentages for categorical variables. Groups were compared using Student's $t$ test or the Mann-Whitney test for continuous variables. Categorical variables were compared using Pearson's chi-square test or Fisher's exact test as appropriate.

In addition to the Cox regression model, the time-varying hazard of waiting list/DDLT was also estimated, reporting the subhazard ratio (SHR) of waiting list/DDLT/dropout with $95 \%$ confidence intervals $(\mathrm{CI})$ in a competing risk (CR) model. To this end, the Fine and Gray method ${ }^{(17)}$ was used, where the association between DDLT and HCC was estimated while accounting for the CR of mortality. This method does not censor the occurrence of death while on the waiting list, thus allowing direct modeling of the subdistribution of the cumulative incidence function of waiting list/DDLT/dropout ${ }^{(18)}$. Fifty-three candidates were excluded from the CR analysis: 29 for clinical improvement (none of them with HCC); 10 for leaving the waiting list (five with HCC); and 14 for being transferred to another transplant center (five with HCC). The final CR model was adjusted for age, MELD score, exception points, and ABO group. Patients who were still on the waiting list were censored on December 31, 2017. Data on demographic characteristics, MELD score on the day of inclusion, date of inclusion, death, exclusion, transplantation, and liver function parameters were recorded for each patient in the cohort.

Data were analyzed using IBM-SPSS version 22.0 (IBM, Armonk, NY, USA) and R version 3.6.0 using the cmprsk package. $P<0.05$ was considered statistically significant.

\section{Ethical approval}

This study was approved by the institutional Research Ethics Committee (approval number: 1.417.586). Informed consent was waived due to the non-interventional design of the study and retrospective nature of data collection. All investigators signed a data use agreement to ensure the ethical and secure use of the data.

\section{RESULTS}

\section{Study population}

From January 1, 2007, to December 31, 2016, 950 patients were listed for DDLT, of whom 125 were excluded from the analysis for the following reasons: need of transplantation for acute liver failure $(n=27)$; retransplantation $(n=42)$; and non-HCC priority exception points $(n=46)$. Therefore, the cohort consisted of 825 patients, divided into two groups: 396 patients listed with a cMELD score and 429 with approved HCC priority exception points for those meeting the Brazilian modified Milan criteria: nodule of at least $2 \mathrm{~cm}$ (one lesion $\geq 2 \mathrm{~cm}$ and $\leq 5 \mathrm{~cm}$, or two or three $\geq 2 \mathrm{~cm}$ and $\leq 3 \mathrm{~cm}$ ) (FIGURE 1).

Demographic data for the groups with and without HCC are shown in TABLE 1. At study entry, patients with HCC were older than patients listed with a cMELD score (median age, 58.3 \pm 7.2 vs $55.0 \pm 10.0$ years; $P<0.001$ ). Most patients were white men with cirrhosis associated with hepatitis $\mathrm{C}$ virus. HCC candidates had significantly lower cMELD scores at study entry than non-HCC candidates (mean $\pm \mathrm{SD}: 18.19 \pm 4.7$ vs $11.8 \pm 4.7 ; P<0.001)$.

\section{HCC and DDLT}

A Cox regression model of time to DDLT and a CR model for HCC were fitted to the data to compare waiting list outcomes. 


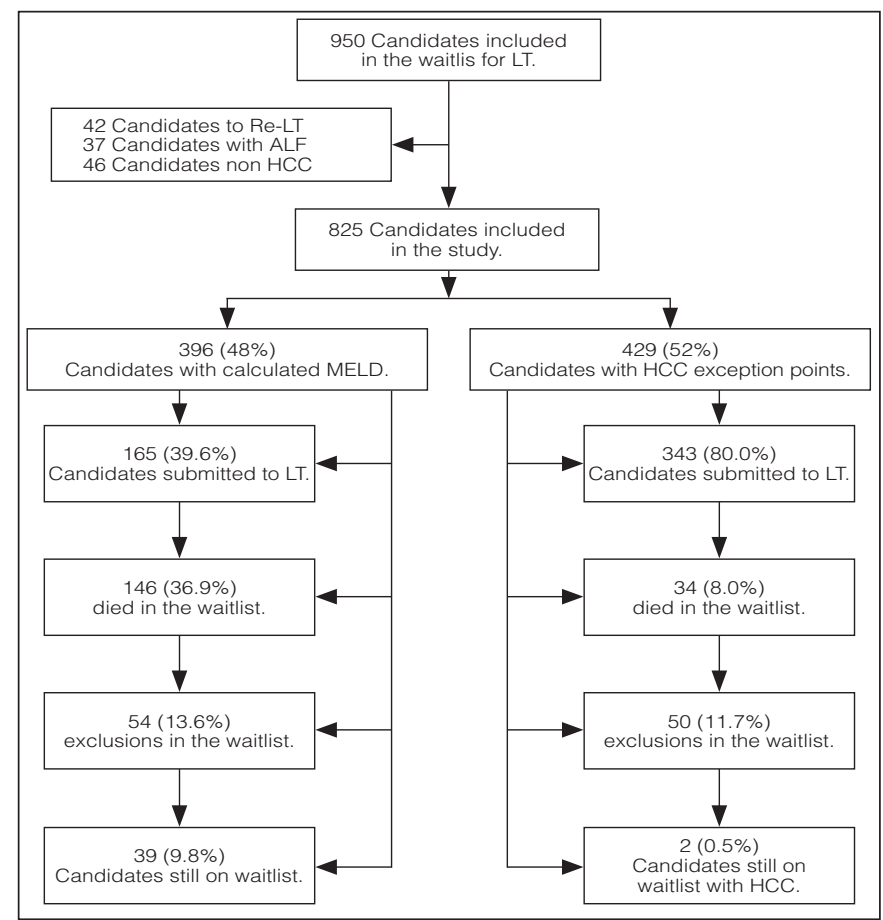

FIGURE 1. Flowchart of deceased donor liver transplantation (DDLT) candidates to be included in the study, according to calculated MELD or hepatocellular carcinoma exception points, January 2007 - December 2016, in Southern Brazil.

TABLE 1. Demographics and clinical parameters of 825 patients included in the waiting list for DDLT stratified according to HCC status - Porto Alegre, Rio Grande do Sul, Brazil.

\begin{tabular}{lccc}
\hline Patients characteristics & $\begin{array}{c}\text { Patients } \\
\text { listed with } \\
\text { HCC (n=429) }\end{array}$ & $\begin{array}{c}\text { Patients listed } \\
\text { without HCC } \\
(\mathrm{n}=396)\end{array}$ & P-value \\
\hline Age at listing (years), mean & $58.3 \pm 7.2$ & $55.0 \pm 10.0$ & $<0.001$ \\
\pm SD & $288(67.1)$ & $276(69.7)$ & 0.429 \\
Male, n (\%) & $16(3.7)$ & $21(5.3)$ & $<0.001$ \\
Etiology of liver disease, n (\%) & $325(75.8)$ & $192(48.5)$ & \\
Hepatitis B & $0(0.0)$ & $6(1.5)$ & \\
Hepatitis C & $43(10.0)$ & $86(21.7)$ & \\
Hepatitis B+C & $27(6.3)$ & $20(5.1)$ & \\
Alcohol & $6(1.4)$ & $27(6.8)$ & \\
NASH & $11(2.6)$ & $43(10.9)$ & \\
Cryptogenic & $1(0.2)$ & $1(0.3)$ & \\
Autoimmune* & & & \\
Other & $389(90.7)$ & $346(88.0)$ & 0.321 \\
Ethnicity, n $(\%)$ & & & 0.122 \\
White & $202(47.1)$ & $155(39.1)$ & \\
Blood type, n (\%) & $42(9.8)$ & $39(9.8)$ & \\
A & $13(3.3)$ & $13(3.0)$ & \\
B & $172(40.1)$ & $189(47.7)$ & \\
AB & $11.8 \pm 3.6$ & $18.1 \pm 4.7$ & $<0.001$ \\
O & & & \\
Calculated MELD score at & & & \\
inclusion, mean \pm SD & & & \\
\hline
\end{tabular}

DDLT: deceased donor liver transplantation; HCC: hepatocellular carcinoma; NASH: nonalcoholic steatohepatitis; MELD: Model for End-Stage Liver Disease. *Autoimmune hepatitis, primary biliary cholangitis, primary sclerosing cholangitis, and hemochromatosis.
Factors included in the model were age, MELD score, exception points, and $\mathrm{ABO}$ group. Candidates with $\mathrm{HCC}$ on the waiting list for DDLT had better outcomes than candidates included with a cMELD score. Patients listed with HCC underwent a transplant almost three times faster than patients listed with a cMELD score (SHR 2.64; 95\% CI 2.10-3.31; $P<0.001$ ) (FIGURE 2). In addition, the DDLT rate per 100 person-months was 11.86 for patients with HCC vs 3.38 for candidates with a cMELD score. The median time on the waiting list was 5.6 months and 25 months for patients with HCC and a cMELD score, respectively.

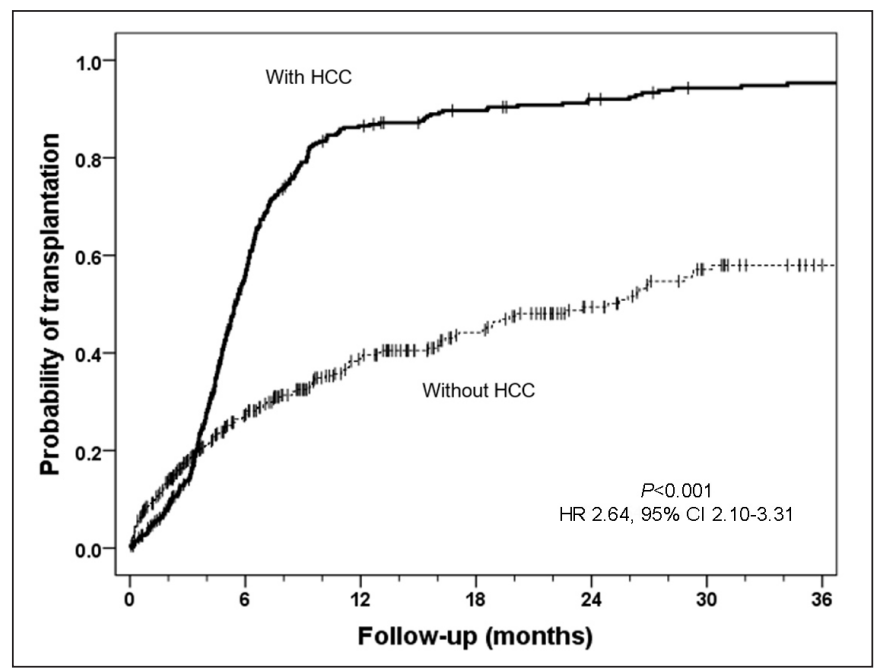

FIGURE 2. Kaplan-Meier chart representing the transplant rate between HCC and non-HCC patients.

\section{Dropout/mortality}

Patients with a cMELD score were 2.39 times more likely to be excluded or to die on the waiting list than patients with HCC (HR $0.42 ; 95 \%$ CI $0.29-0.60 ; P<0.001$ ). The event rate per 100 person-months was 2.93 for patients with a cMELD score vs 1.20 for patients with $\mathrm{HCC}$.

The most common causes of death in both groups with and without HCC were complications of liver disease ( $24.3 \%$ vs $25.3 \%$ respectively), infectious causes (13\% vs $37 \%$ respectively), and cardiovascular causes ( $7.7 \%$ vs $7.5 \%$ respectively).

\section{DISCUSSION}

After the implementation of the MELD-based allocation system, coupled with HCC exception points, studies in large North American databases have shown that patients with HCC consistently had greater access to DDLT and lower dropout rates than candidates included in the waiting list without $\operatorname{HCC}^{(9,10,12,19)}$. Consequently, the liver allocation policy adopted by the United Network for Organ Sharing (UNOS) for HCC patients was altered to reduce this distortion ${ }^{(16)}$. Currently, in the United States, HCC patients are listed with a cMELD score in the first six months on the list. Patients who are still within the transplant criteria after six months receive a MELD score of 28, which increases every three months, up to a maximum of $34^{(20)}$.

In Brazil, the MELD score has been used in the allocation of grafts for DDLT since $2006^{(1)}$. To allow access to liver transplantation for patients with HCC within the Brazilian modified Milan criteria 
(one tumor $2-5 \mathrm{~cm}$ or $2-3$ tumors of $2-3 \mathrm{~cm}$ each), HCC patients are granted extra points: 20 points at listing, 24 after three months, and 29 after six months. In our setting, after the implementation of the MELD score in graft allocation, the number of HCC patients undergoing a transplant increased in the post-MELD era $^{(21-23)}$.

Patients listed for transplantation have three potential outcomes: a) transplant; b) death on the waiting list or withdrawal from the list while alive for any reason; or c) still awaiting transplantation. Each of these outcomes is CR with others, since the occurrence of one of them prevents or impairs the others. Thus, the CR statistical method was used in this study, which seems to be the most appropriate for the analysis of waiting list outcomes ${ }^{(24)}$. Our study, conducted in a single Brazilian center, showed that patients on the DDLT waiting list with HCC had higher transplantation rates, lower rates of death while on the waiting list, and shorter waiting time than patients on the waiting list with a cMELD score. In this cohort, patients with a cMELD score had a 2.39 times higher probability of death on the waiting list than patients with HCC. Therefore, it is clear that the current Brazilian allocation policy needs to be revised to reduce the disparity between these two groups, with and without HCC.

Patients with HCC are more likely to be included in the waiting list ${ }^{(25)}$, while improvements in locoregional therapies have allowed tumor growth and dropout rates to be reduced ${ }^{(26,27)}$. Thus, HCC patients are being unintentionally benefited to the detriment of patients listed with a cMELD score, for whom the only available treatment is liver transplantation. In addition, it has been widely discussed whether liver transplantation would bring benefits to patients with HCC and preserved liver function ${ }^{(28-30)}$. Therefore, the introduction of policies that allow greater equity in the access to DDLT between these 2 groups of patients, with and without $\mathrm{HCC}$, is extremely necessary. UNOS has adopted the policy of not assigning any special scores to HCC patients in the first six months on the list, but other allocation suggestions can and should be evaluated to be eventually used in Brazil ${ }^{(12,31-33)}$.

Our study has some limitations. First, we acknowledge those limitations inherent in retrospective studies and the fact that the study was conducted in a single center. However, the long study period allowed us to identify the impact of current allocation policies on the different primary endpoints related to the waiting list. The outcomes of candidates with HCC were those already observed within the current allocation system. Therefore, we cannot confirm whether transplantation rates, risk of death, and clinical deterioration on the waiting list would be the same if patients with $\mathrm{HCC}$ had not received exception points. Although it is theoretically possible that fewer candidates with $\mathrm{HCC}$ would have undergone a transplant and more candidates would have been removed from the list for death or clinical deterioration, this is an unlikely explanation for the results obtained in our study given the magnitude of the differences between the two groups, with and without HCC. It is also important to note that patients listed with a cMELD score had a high waiting list mortality rate and that more than $50 \%$ of the cohort patients had HCC in a region with a high prevalence of hepatitis $\mathrm{C}$ virus infection ${ }^{(34)}$.

\section{CONCLUSION}

Our results showed that, in our center, patients on the waiting list with HCC have a clear advantage over candidates listed with a cMELD score in terms of transplantation rate, lower mortality rate, and time on the waiting list. It is important to develop a system that reflects the real risk of dropout, including factors such as response to locoregional therapy, severity of underlying liver disease, regional access to transplantation, and graft availability.

\section{ACKNOWLEDGEMENTS}

The authors thank the Liver Transplantation Group at Santa Casa de Misericórdia de Porto Alegre, RS, Brazil. The authors would also like to thank Professor Dr. Mário Wagner for his assistance with statistical analysis.

\section{Authors' contribution}

Rodríguez S: conceptualized and designed the data, collected the data, analyzed and interpreted the data, drafted the article, and critically revised the article. Fleck Jr AM, Mucenic M, Marroni $\mathrm{C}$ : critically revised the article. Brandão A: conceptualized and designed the data, collected the data, analyzed and interpreted the data, drafted the article, and critically revised the article.

\section{Orcid}

Santiago Rodríguez. Orcid: 0000-0001-8610-3622.

Alfeu de Medeiros Fleck Jr. Orcid: 0000-0002-0424-6919.

Marcos Mucenic. Orcid: 0000-0001-9389-2236.

Cláudio Marroni. Orcid: 0000-0002-1718-6548.

Ajacio Brandão. Orcid: 0000-0001-8411-5654.

Rodríguez S, Fleck Jr AM, Mucenic M, Marroni C, Brandão A. Pacientes com carcinoma hepatocelular são favorecidos no atual sistema brasileiro de alocação de fígados para transplante. Análise de riscos competitivos. Arq Gastroenterol. 2020;57(1):19-23.

RESUMO - Contexto - No Brasil, o escore MELD (Model for End-Stage Liver Disease) é utilizado para priorizar os pacientes para transplante hepático de doador falecido (THDF). Pacientes com carcinoma hepatocelular (CHC) recebem pontos de exceção padronizados pelo MELD para contrapesar o risco de mortalidade do seu câncer, que não é refletido pelo seu escore MELD. Objetivo - Comparar as taxas de THDF entre pacientes com e sem CHC no Rio Grande do Sul, o Estado mais ao sul do Brasil. Métodos - Foram estudados retrospectivamente 825 pacientes em lista de espera de transplante de fígado entre 1 de janeiro de 2007 e 31 de dezembro de 2016 em um centro de transplantes localizado em Porto Alegre, capital do Rio Grande do Sul, para comparação das taxas de THDF entre aqueles com e sem CHC. Foi estimado o risco variável no tempo de lista de espera/THDF, com relato da taxa de sub-risco (SHR) de lista de espera/THDF/desistência com intervalos de confiança (IC) de $95 \%$. O modelo final de risco competitivo foi ajustado para idade, escore MELD, pontos de exceção e grupo ABO. Resultados - Os candidatos com CHC foram submetidos a um transplante quase três vezes mais rápido do que os pacientes com um escore MELD calculado (SHR 2,64; IC 95\% 2,10-3,31; $P<0,001$ ). A taxa de THDF por 100 pessoas-mês foi de 11,86 para os pacientes com CHC vs 3,38 para os pacientes sem CHC. O tempo mediano de permanência em lista de espera foi de 5,6 meses para os pacientes com CHC e 25 meses para os pacientes sem CHC. Conclusão - Nossos resultados demonstraram que, em nosso centro, pacientes em lista de espera com CHC têm evidente vantagem sobre candidatos listados com um escore MELD calculado.

DESCRITORES - Transplante de fígado. Carcinoma hepatocelular. Transplante de órgãos. Disparidades em assistência à saúde. 


\section{REFERENCES}

1. Brasil. Portaria 1.160, de 29 de maio de 2006 [Internet]. Brasília: Ministério da Saúde; 2006. [Internet]. [cited 2018 June 11]. Available from: http://bvsms.saude. gov.br/bvs/saudelegis/gm/2006/prt1160_29_05_2006_comp.html.

2. Freeman Jr RB, Wiesner RH, Roberts JP, McDiarmid S, Dykstra DM, Merion RM. Improving liver allocation: MELD and PELD. Am J Transplant. 2004;4(Suppl 9):114-31.

3. Brandão A, Fuchs SC, Gleisner AL, Marroni C, Zanotelli ML, Cantisani G. Model for the end-stage liver disease and death prediction in a cohort of Brazilian patients on the waitlist for liver transplantation. Clin Transplant. 2008;22:651-6.

4. Barbara L, Benzi G, Gaiani S, Fusconi F, Zironi G, Siringo S, et al. Natural history of small untreated hepatocellular carcinoma in cirrhosis: a multivariate analysis of prognostic factors of tumor growth rate and patient survival. Hepatology. 1992;16:132-7.

5. Cheng SJ, Freeman Jr RB, Wong JB. Predicting the probability of progression-free survival in patients with small hepatocellular carcinoma. Liver Transpl. 2002;8:323-8.

6. Roayaie K, Feng S. Allocation policy for hepatocellular carcinoma in the MELD era: room for improvement? Liver Transpl. 2007;13(11 Suppl 2):S36-43.

7. Schilsky ML, Moini M. Advances in liver transplantation allocation systems. World J Gastroenterol. 2016;22:2922-30.

8. Wiesner RH, Freeman RB, Mulligan DC. Liver transplantation for hepatocellular cancer: the impact of the MELD allocation policy. Gastroenterology. 2004;127(5 Suppl 1):S261-7.

9. Freeman RB, Edwards EB, Harper AM. Waitlist removal rates among patients with chronic and malignant liver diseases. Am J Transplant. 2006;6:1416-21.

10. Washburn K, Edwards E, Harper A, Freeman R. Hepatocellular carcinoma patients are advantaged in the current liver transplant allocation system. Am J Transplant. 2010;10:1643-8.

11. Toso C, Dupuis-Lozeron E, Majno P, Berney T, Kneteman NM, Perneger T, et al. A model for dropout assessment of candidates with or without hepatocellular carcinoma on a common liver transplant waitlist. Hepatology. 2012;56:149-56.

12. Northup PG, Intagliata NM, Shah NL, Pelletier SJ, Berg CL, Argo CK. Excess mortality on the liver transplant waitlist: unintended policy consequences and Model for End-Stage Liver Disease (MELD) inflation. Hepatology. 2015;61:285-91.

13. Organ Procurement \& Transplantation Network (OPTN). HCC policy changes affect applications for non-automatic exception requests [Internet]. Washington: OPTN; 2015 [cited 2019 Aug 08]. Available from: https://optn.transplant.hrsa. gov/news/hcc-policy-changes-affect-applications-for-non-automatic-exceptionrequests/

14. Bruix J, Sherman M, Llovet JM, Beaugrand M, Lencioni R, Burroughs AK, et al. Clinical management of hepatocellular carcinoma. Conclusions of the Barcelona-2000 EASL conference. J Hepatol. 2001;35:421-30.

15. Bruix J, Sherman M; Practice Guidelines Committee, American Association for the Study of Liver Diseases. Management of hepatocellular carcinoma. Hepatology. 2005;42:1208-36.

16. Jarnagin W, Chapman WC, Curley S, D’Angelica M, Rosen C, Dixon E, et al. Surgical treatment of hepatocellular carcinoma: expert consensus statement. HPB (Oxford). 2010;12:302-10.

17. Fine JP, Gray RJ. A proportional hazards model for the subdistribution of a competing risk. J Am Stat Assoc. 1999;94:496-509.

18. Lau B, Cole SR, Gange SJ. Competing risk regression models for epidemiological data. Am J Epidemiol. 2009;170:244-56.
19. Goldberg D, French B, Abt P, Feng S, Cameron AM. Increasing disparity in waitlist mortality rates with increased model for end-stage liver disease scores for candidates with hepatocellular carcinoma versus candidates without hepatocellular carcinoma. Liver Transpl. 2012;18:434-43.

20. Alcorn JB. Changes to OPTN bylaws and policies from actions at November board of directors meeting [Internet]. Washington: United Network for Organ Sharing; 2014 [cited 2018 June 11]. Available from: https://optn.transplant.hrsa. gov/media/1140/policy_notice_12-2014.pdf.

21. Machado AGS, Fleck Jr AM, Marroni C, Zanotelli ML, Cantisani G, Brandão ABM. Impact of MELD score implementation on liver allocation: experience at a Brazilian center. Ann Hepatol. 2013;12:440-7.

22. Coelho GR, Feitosa Neto BA, Teixeira CCG, Marinho DS, Rangel ML, Garcia JH. Single-center transfusion rate for 555 consecutive liver transplantations: impact of two eras. Transplant Proc. 2013;45:3305-9.

23. Pestana RC, Baracat EI, Massarollo PC, Pereira LA, Szutan LA. Consequences of the implementation of the Model for End-stage Liver Disease system for liver allocation in Brazil. Transplant Proc. 2013;45:2111-4.

24. Kim WR, Therneau TM, Benson JT, Kremers WK, Rosen CB, Gores GJ, et al. Deaths on the liver transplant waitlist: an analysis of competing risks. Hepatology. 2006;43:345-51.

25. Goldberg D, French B, Newcomb C, Liu Q, Sahota G, Wallace AE, et al. Patients with hepatocellular carcinoma have highest rates of wait-listing for liver transplantation among patients with end-stage liver disease. Clin Gastroenterol Hepatol. 2016;14:1638-46.e2.

26. Golfieri R, Cappelli A, Cucchetti A, Piscaglia F, Carpenzano M, Peri E, et al. Efficacy of selective transarterial chemoembolization in inducing tumor necrosis in small $(<5 \mathrm{~cm})$ hepatocellular carcinomas. Hepatology. 2011;53:1580-9.

27. Cucchetti A, Cescon M, Bigonzi E, Piscaglia F, Golfieri R, Ercolani G, et al. Priority of candidates with hepatocellular carcinoma awaiting liver transplantation can be reduced after successful bridge therapy. Liver Transpl. 2011;17:1344-54.

28. Berry K, Ioannou GN. Comparison of liver transplant-related survival benefit in patients with versus without hepatocellular carcinoma in the United States. Gastroenterology. 2015;149:669-80; quiz e615-6.

29. Berry K, Ioannou GN. Are patients with Child's A cirrhosis and hepatocellular carcinoma appropriate candidates for liver transplantation? Am J Transplant. 2012;12:706-17.

30. Cillo U, Vitale A, Polacco M, Fasolo E. Liver transplantation for hepatocellular carcinoma through the lens of transplant benefit. Hepatology. 2017;65:1741-8.

31. Vitale A, Volk ML, de Feo TM, Burra P, Frigo AC, Morales RR, et al. A method for establishing allocation equity among patients with and without hepatocellular carcinoma on a common liver transplant waitlist. J Hepatol. 2014;60:290-7.

32. Heimbach JK, Hirose R, Stock PG, Schladt DP, Xiong H, Liu J, et al. Delayed hepatocellular carcinoma model for end-stage liver disease exception score improves disparity in access to liver transplant in the United States. Hepatology. 2015;61:1643-50

33. Mehta N, Dodge JL, Hirose R, Roberts JP, Yao FY. Predictors of low risk for dropout from the liver transplant waitlist for hepatocellular carcinoma in long wait time regions: Implications for organ allocation. Am J Transplant. 2019;19:2210-8.

34. Secretaria de Vigilância em Saúde. Ministério da Saúde. Boletim epidemiológico. Hepatites Virais 2019. Biblioteca Virtual em Saúde do Ministério da Saúde. [Internet]. Available from: http://www.aids.gov.br/pt-br/pub/2019/boletim-epidemiologico-de-hepatites-virais-2019. 